\title{
Begonia myanmarica (Begoniaceae), a new species from Myanmar, and molecular phylogenetics of Begonia sect. Monopteron
}

Yu-Hsin Tseng ${ }^{1}$, Young-Dong Kim ${ }^{2 *}$, Ching-l Peng ${ }^{1}$, Khin Myo Htwe ${ }^{3}$, Seong-Hyun Cho ${ }^{4}$, Yoshiko Kono ${ }^{1}$ and Kuo-Fang Chung ${ }^{1 *}$

\begin{abstract}
Background: A new species, Begonia myanmarica, was discovered from Myanmar and herein documented. Characterized by a single developed wing in the ovary/fruit, this species would be assigned to sect. Monopteron (sensu Doorenbos et al. in The sections of Begonia including descriptions, keys and species lists: studies in Begoniaceae VI. Wageningen Agricultural University, Wageningen, 1998) that is known by B. griffithiana and B. nepalensis from the Himalaya. To confirm its sectional assignment, we conducted morphological, phylogenetic and cytological studies.

Results: Morphological observations indicated that B. myanmarica was distinguishable from the two known species of sect. Monopteron by the leaf shape and size, 1-locular ovary, parietal placentation and chromosome number. Molecular phylogenetic analysis using nrlTS sequences showed that B. myanmarica was not allied with the clade of sect. Monopteron, though both were nested within sect. Platycentrum-sect. Sphenanthera clade.

Conclusions: Studies of morphology, molecular phylogenetics and cytology support the recognition of the new species, Begonia myanmarica, which is fully described and illustrated. Our results also indicate that B. myanmarica is not closely related to species previously assigned to sect. Monopteron, suggesting that the fruit morphology of a single developed wing in the ovary/fruit characterizing sect. Monopteron is homoplasious.
\end{abstract}

Keywords: Begonia griffithiana, Begonia nepalensis, Chromosome, Morphology

\section{Background}

Begonia L. (Begoniaceae), comprising more than 1800 species classified into 68 sections (Doorenbos et al. 1998; Hughes et al. 2015; Christenhusz and Byng 2016), is one of the largest genera of vascular plants. With more than 760 Begonia species in Asia, Doorenbos et al. (1998) recognized 18 sections [Alicida C.B. Clarke, Apterobegonia Warb., Baryandra A. DC., Bracteibegonia A. DC., Coleocentrum Irmscher, Diploclinium (Lindl.) A. DC., Haagea (Klotzsch) A. DC., Heeringia Irmscher, Lauchea (Klotzsch) A. DC., Monophyllon A. DC., Monopteron

\footnotetext{
*Correspondence: ydkim@hallym.ac.kr; bochung@gate.sinica.edu.tw ${ }^{1}$ Research Museum and Herbarium (HAST), Biodiversity Research Center, Academia Sinica, Taipei 11542, Taiwan

2 Department of Life Science, Hallym University, Chuncheon, Gangwon 24252, Republic of Korea

Full list of author information is available at the end of the article
}

(A. DC.) Warb., Parvibegonia A. DC., Petermannia (Klotzsch) A. DC., Platycentrum (Klotzsch) A. DC., Putzeysia (Klotzsch) A. DC., Reichenheimia (Klotzsch) A. DC., Ridleyella Irmscher, and Sphenanthera (Hassk.) Warb.]. Thereafter, four additional Asian sections were proposed [Leprosae (T.C. Ku) Y.M. Shui, Monolobium T.C. Ku, Pleiothece T.C. Ku, and Symbegonia (Warb.) G. Forrest \& Hollingsw.] (Ku 1999; Shui et al. 2002; Forrest and Hollingsworth 2003; Ku et al. 2007). These 22 Asian sections are highly unequal in species numbers: eight of the large sections (Petermannia, Platycentrum, Diploclinium, Reichenheimia, Coleocentrum, Parvibegonia, Sphenanthera, and Symbegonia) comprise 95\% of Asian Begonia species and the rest 14 sections each with less than five species (Thomas 2010). Several molecular phylogenetic studies have demonstrated the paraphyly or polyphyly of these large sections, suggesting homoplasy 
of morphological characters used for current sectional delimitations (Tebbitt et al. 2006; Thomas et al. 2011; Chung et al. 2014). However, few studies have tested the monophyly of small Asian section of Begonia thus far [but see Rajbhandary (2010); Rubite (2010); Thomas (2010)].

Myanmar is botanically a most interesting country, but there have been no critical floristic surveys for nearly half a century. Thus far about 60 species of Begonia have been recorded from Myanmar (Hughes 2008; Tanaka and Hughes 2007; Tanaka and Hayami 2011; Peng et al. 2014b; Tanaka and Peng 2016). During the fieldwork in western Myanmar on 2 February 2012, the second author (YDK) collected an unknown Begonia with only one developed wing in ovary/fruit, which is the key character of Begonia sect. Monopteron sensu Doorenbos et al. (1998) first delimited by de Candolle (1864) as Mezierea sect. Monopteron. Presently, only two species, B. griffithiana Warb. and B. nepalensis Warb., are recognized in sect. Monopteron (de Candolle 1864; Doorenbos et al. 1998). Begonia nepalensis, the type species of sect. Monopteron, is native to Bhutan, Nepal and India (Fig. 5; Doorenbos et al. 1998; Hughes et al. 2015). Its chromosome number was reported to be $2 n=16$ (Legro and Doorenbos 1971), with an uncertain chromosome count $2 n=28-42$ by Sharma and Bhattacharyya (1961). Begonia griffithiana, occurring in Bhutan and India (Fig. 5), is characterized by lanceolate to oblong leaves with subcordate base. Chromosome number of $B$. griffithiana was documented as $2 n=22$ (Doorenbos et al. 1998). Based on recent systematics and phylogenetics of Begonia, sect. Monopteron is nested within the Platycentrum-Sphenanthera clade (Rubite 2010; Thomas 2010; Rajbhandary et al. 2011; Leong 2017).

Although morphology of the 1-winged ovary/capsule of the undescribed Begonia should be assigned to sect. Monopteron, it differs from B. griffithiana and B. nepalensis significantly the leaf shape, leaf size and distribution. In this study, we described it as a new species. We also provide detailed morphological data and molecular phylogenetic analysis to elucidate the sectional assignment for this species.

\section{Methods}

\section{Morphological observations}

Rhizomes of Begonia myanmarica collected by YDK from Myanmar were cultivated in the experimental greenhouse of the Biodiversity Research Center, Academia Sinica, Taipei, Taiwan. Fully grown plants with flowers and fruits (Peng 23565, 23566) were used for morphological observation. The two species of sect.
Monopteron, B. griffithiana (Peng 20851) and B. nepalensis (Peng 20854), cultivated in the greenhouse were also studied as a comparison.

\section{Chromosome preparations}

Root tips were obtained from cultivated materials from greenhouse of Academic Sinica. Somatic chromosome of the new species, B. myanmarica (Peng 23566), and two species of sect. Monopteron: B. griffithiana (Peng 20851) and B. nepalensis (Peng 20854), were examined using root tips following the methods by Peng et al. (2014a).

\section{Phylogenetic analyses}

DNA sequences of the nuclear ribosomal internal transcribed spacer (nrITS) were used to evaluate the phylogenetic relationship among new species and the two species of sect. Monopteron. DNA extraction, PCR amplification and DNA sequencing followed Chung et al. (2014). To test the monophyly of sect. Monopteron and sectional assignment of new species, nrITS of 96 species used in Chung et al. (2014) were adopted for phylogenetic analysis (see Appendix for details). Alignment was conducted using MUSCLE implemented in MEGA5.2 (Tamura et al. 2011) and verified in Mesquite v3.03 (Maddison and Maddison 2015). Phylogenetic relationships were constructed by Bayesian Inference (BI) method. The best nucleotide substitution models were determined by Modeltest v2.7 (Posada and Crandall 1998). For BI analysis, the consensus topology was based on Markov chains algorithm implemented in MRBAYES 3.0b4 (Huelsenbeck and Ronquist 2001). Four chains of Markov chain Monte Carlo (MCMC) simulation were carried out for $1,500,000$ generations each with trees sampled per 500 generations. The first 500 trees of sampled trees were discarded before the node probability was calculated (posterior probability: $\mathrm{PP}$ ).

\section{Taxonomic treatment}

Begonia myanmarica C.-I Peng \& Y. D. Kim, sp. nov. (Figs. 1, 2)

\section{Type}

MYANMAR. Sagaing Region, Alangdaw Kathapa National Park, $22^{\circ} 18^{\prime} 47.7^{\prime \prime}$ N, 94 $28^{\prime} 32.7^{\prime \prime}$ E, alt. $438 \mathrm{~m}$, mixed deciduous forest, along the stream. Living collection made by Seong-hyun Cho, Young-dong Kim, Yong-in Kim E Jeong-hun Lee MM-0611, 2 Feb 2012; type specimens (with flowers and fruits) pressed from plants cultivated in the experimental greenhouse, Academia Sinica, Taipei, Taiwan, 20 Mar 2016, Ching-I Peng 23566 (holotype: RAF; isotypes: HAST, KB). 

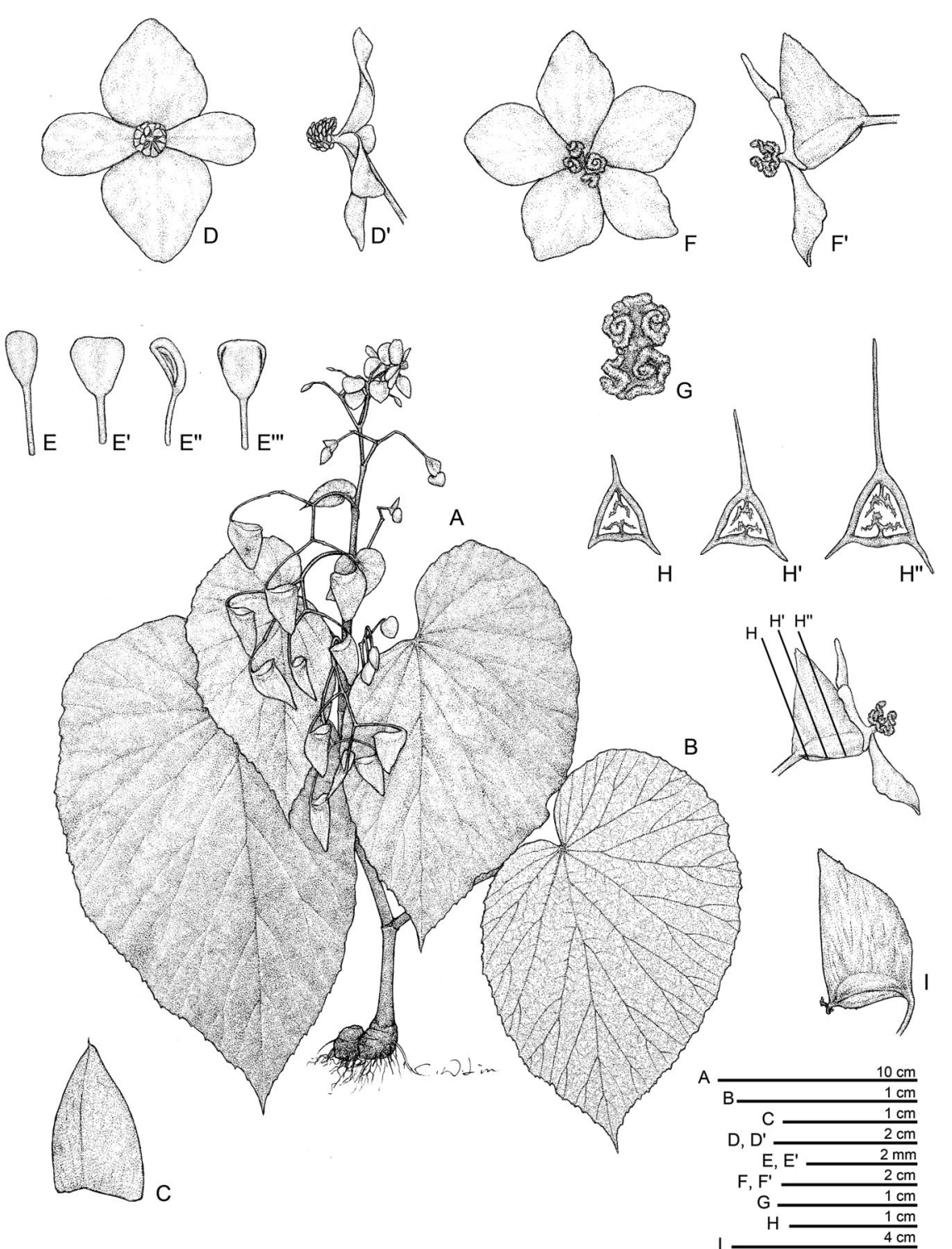

Fig. 1 Begonia myanmarica C.-I Peng \& Y. D. Kim. A Habit. B Leaf adaxial surface. C Stipule. D Male flower, face view, D' Male flower, side view. E, E', $\mathbf{E}^{\prime \prime}, \mathbf{E}^{\prime \prime \prime}$ Stamen. F Female flower, face view, $\mathbf{F}^{\prime}$ Female flower, side view. G Style and stigma. H, $\mathbf{H}^{\prime}, \mathbf{H}^{\prime \prime}, \mathbf{H}^{\prime \prime \prime}$ Cross section of ovary. I Capsule

\section{Diagnosis}

Begonia myanmarica is a unique species with an erect habit; large, ovate to broadly ovate leaves (ca. $20-40 \mathrm{~cm}$ long, 22-30 mm across); sole, much protruded wing in ovary/fruit; 1-locular ovary with parietal placentation and 2 placentae; and the somatic chromosomes are determined as $2 n=38$.
Herbs monoecious, perennial. Rhizomes stout, $2-4 \mathrm{~cm}$ across, to $9 \mathrm{~cm}$ long; erect stem $50-90 \mathrm{~cm}$ tall, $1-2 \mathrm{~cm}$ thick, internodes 5-15 cm, glabrous. Stipules caducous, glabrous, triangular, apex aristate or apiculate, margin entire, 7-15 mm long, 6-15 mm wide. Leaves alternate, green with slightly paler veins; petiole $20-40 \mathrm{~cm}$ long, $2.2-3 \mathrm{~cm}$ across, glabrous; leaf blade fleshy, asymmetric, 


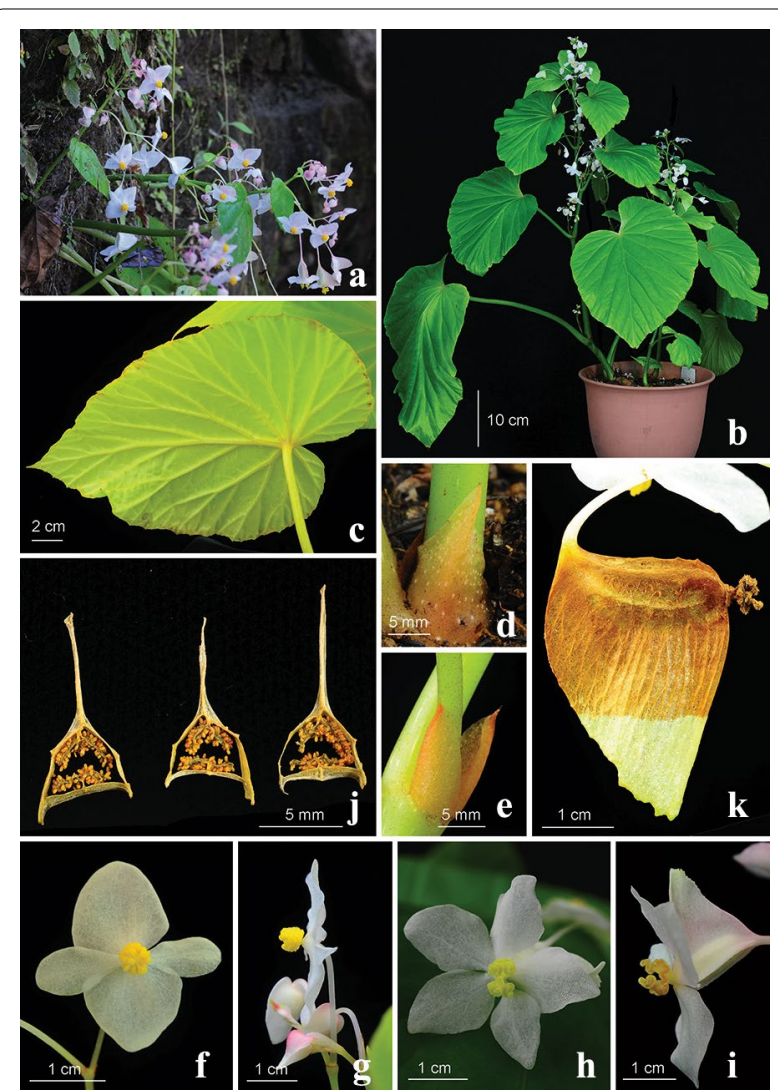

Fig. 2 Begonia myanmarica C.-I Peng \& Y. D. Kim. a Habit and habitat. b Cultivated plant at anthesis. c Leaf abaxial view. d Stipule. e Bract. $\mathbf{f}$ Male flower, face view. $\mathbf{g}$ Male flower, side view. $\mathbf{h}$ Female flower, face view. i Female flower, side view. $\mathbf{j}$ Cross section of ovaries. $\mathbf{k}$ Capsule

ovate to broadly ovate, $21-35 \mathrm{~cm}$ long, $15-28 \mathrm{~cm}$ wide, upper surface glabrous, underside slightly hairy on veins, base obliquely cordate, margin irregularly loosely serrulate or denticulate, apex acute or short acuminate; venation 7-or 8-palmate. Inflorescence mainly terminal but also axillary racemes of dichasial cymes, bisexual, protandrous; cyme 10-15 cm long, with 2 female flowers at apex and 7-9 male flowers at base, peduncle $2-5 \mathrm{~cm}$ long, glabrous; bracts deciduous, ovate to triangular, apex acuminate, margin entire, $0.7-1.5 \mathrm{~cm}$ long, $0.4-0.6 \mathrm{~cm}$ wide. Male flower: pedicel $2-2.8 \mathrm{~cm}$ long, glabrous; tepals 4 , white to pinkish, outer 2 ovate or orbicular, $1.9-2.3 \mathrm{~cm}$ long, $1.5-2 \mathrm{~cm}$ wide, inner 2, broadly oblong, $1.8-2.3 \mathrm{~cm}$ long, $0.5-1.5 \mathrm{~cm}$ wide, glabrous; androecium actinomorphic, subglobose, ca. $0.7 \mathrm{~cm}$ across, stamens 60-80, yellow, clavate; filaments ca. $2 \mathrm{~mm}$ long, fused to a short central column; anthers 1-1.2 mm long, apex truncate. Female flower: pedicel $1.7-3.5 \mathrm{~cm}$ long, glabrous; ovary white, wings 3 , manifestly unequal, 2 side wings almost undeveloped, abaxial wing much protruded, white to pale greenish or pinkish, 1-locular; placentation parietal, placentae 2, each bilamellate; tepals 5 , white in the greenhouse (pinkish in the wild), unequal, elliptic to obovate, $1.5-2 \mathrm{~cm}$ long, $0.5-1.1 \mathrm{~cm}$ wide, apex obtuse; styles 2, ca. $5 \mathrm{~mm}$ long, 2- or 3-cleft, fused at base, stigmatic band wavy-twisted and spiralled. Capsule nodding, stalk $3.5-5.5 \mathrm{~cm}$ long, abaxial wing triangular to rectangular, $2.4-3.8 \mathrm{~cm}$ tall, $2.0-2.4 \mathrm{~cm}$ wide, lateral two wings barely developed, rounded, $0.2-0.4 \mathrm{~cm}$ tall, $1.8-2.2 \mathrm{~cm}$ wide. Seeds barrel-shaped, $0.25-0.3 \mathrm{~mm}$ long.

\section{Distribution and habit}

Known only from the type locality.

\section{Etymology}

The epithet refers to Myanmar (formerly Burma) where it was discovered.

\section{Additional specimens examined}

MYANMAR. Sagaing Region: Alang Daw Kathapa National Park, $22^{\circ} 18^{\prime} 47.7^{\prime \prime}$ N, 94 $28^{\prime} 32.7^{\prime \prime}$ E, 438 m, 2 Feb 2012, Peng 23565 (HAST); $22^{\circ} 18^{\prime} 49.5^{\prime \prime} \mathrm{N}, 94^{\circ} 28^{\prime} 30.2^{\prime \prime}$ E, $434 \mathrm{~m}, 2$ Feb 2012, MM-0556 (KB); $22^{\circ} 18^{\prime} 47.7^{\prime \prime} \mathrm{N}$, 94 $28^{\prime} 32.7^{\prime \prime}$ E, 438 m, 2 Feb 2012, MM-0611 (KB, HHU); $22^{\circ} 18^{\prime} 44.2^{\prime \prime} \mathrm{N}, 94^{\circ} 28^{\prime} 28.7^{\prime \prime}$ E, 380 m, 2 Feb 2012, $M M-$ 0616 (KB); $22^{\circ} 19^{\prime} 25^{\prime \prime} \mathrm{N}, 94^{\circ} 29^{\prime} 37.7^{\prime \prime}$ E, 380 m, 5 Feb 2012, MM-0848 (KB, RAF).

\section{Chromosome cytology}

Somatic chromosome at metaphase of B. myanmarica were shown to be $2 n=38$ in this study (Fig. 4c).

\section{Discussion}

Begonia myanmarica has only one developed wing in ovary/fruit (Figs. 2k, 3c, d), the key character of sect. Monopteron in Begonia (Doorenbos et al. 1998). The new species, however, deviates from sect. Monopteron with axillary placentation and two locules in ovary (Fig. 3e, f) in having 1-locular ovary and parietal placentation (Fig. 2j). Additionally, B. myanmarica has ovate to broadly ovate leaves and large leaves (ca. $20-40 \mathrm{~cm}$ long, 22-30 mm across) (Fig. 2b, c), whereas leaves of B. griffithiana and $B$. nepalensis are lanceolate to oblong and no longer than $20 \times 10 \mathrm{~cm}$ (Fig. 3a, b). Cytologically, 

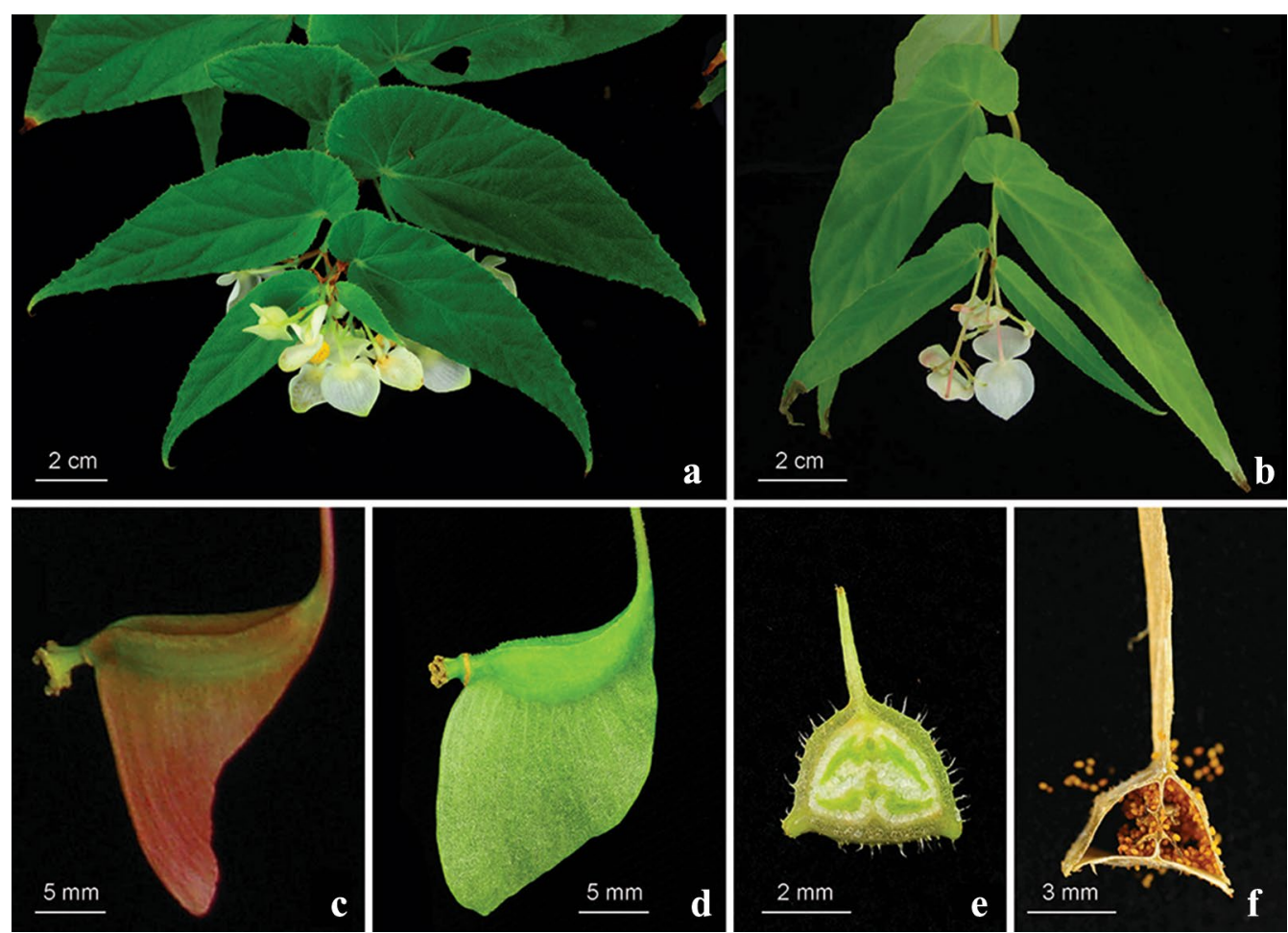

Fig. 3 Overview of leaves, fruit and cross section of ovary in Begonia griffithiana and B. nepalensis. a, b Leaves. c, d Fruit. e, f Cross section of ovary. Begonia griffithiana $(\mathbf{a}, \mathbf{c}, \mathbf{e})$. Begonia nepalensis $(\mathbf{b}, \mathbf{d}, \mathbf{f})$

somatic chromosome of $B$. myanmarica is determined to be $2 n=38$ (Fig. 4c), while chromosomes of B. griffithiana and B. nepalensis are both $2 n=16$ (Fig. 4a, b) in our study. Geographically, B. myanmarica is endemic to Myanmar while B. griffithiana and B. nepalensis are distributed in India, Nepal and Bhutan (Fig. 5). We concluded that $B$. myanmarica is sharply distinct from $B$. griffithiana and B. nepalensis.
In our molecular phylogenetic study, B. griffithiana and $B$. nepalensis form a strongly supported clade (posterior probability, $\mathrm{PP}=1$ ) nested within the clade dominated by sect. Platycentrum-sect. Sphenanthera clade [Fig. 6; Clade PLA-SPH in Chung et al. (2014)], congruent with the studies of Rubite (2010), Thomas (2010), Rajbhandary et al. (2011), and Leong (2017). Two sampled individuals of B. myanmarica also fall within the Clade PLA-SPH
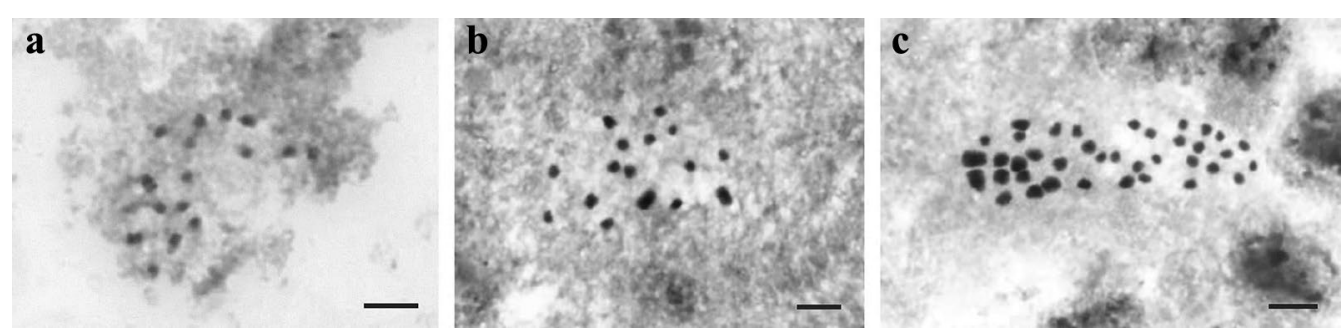

Fig. 4 Somatic chromosomes at metaphase of Begonia. a B. griffithiana $(2 n=16$, Peng 20851). b B. nepalensis $(2 n=16$, Peng 20854). c B. myanmarica $(2 n=38$, Peng 23566). Scale bar $5 \mu \mathrm{m}$ 


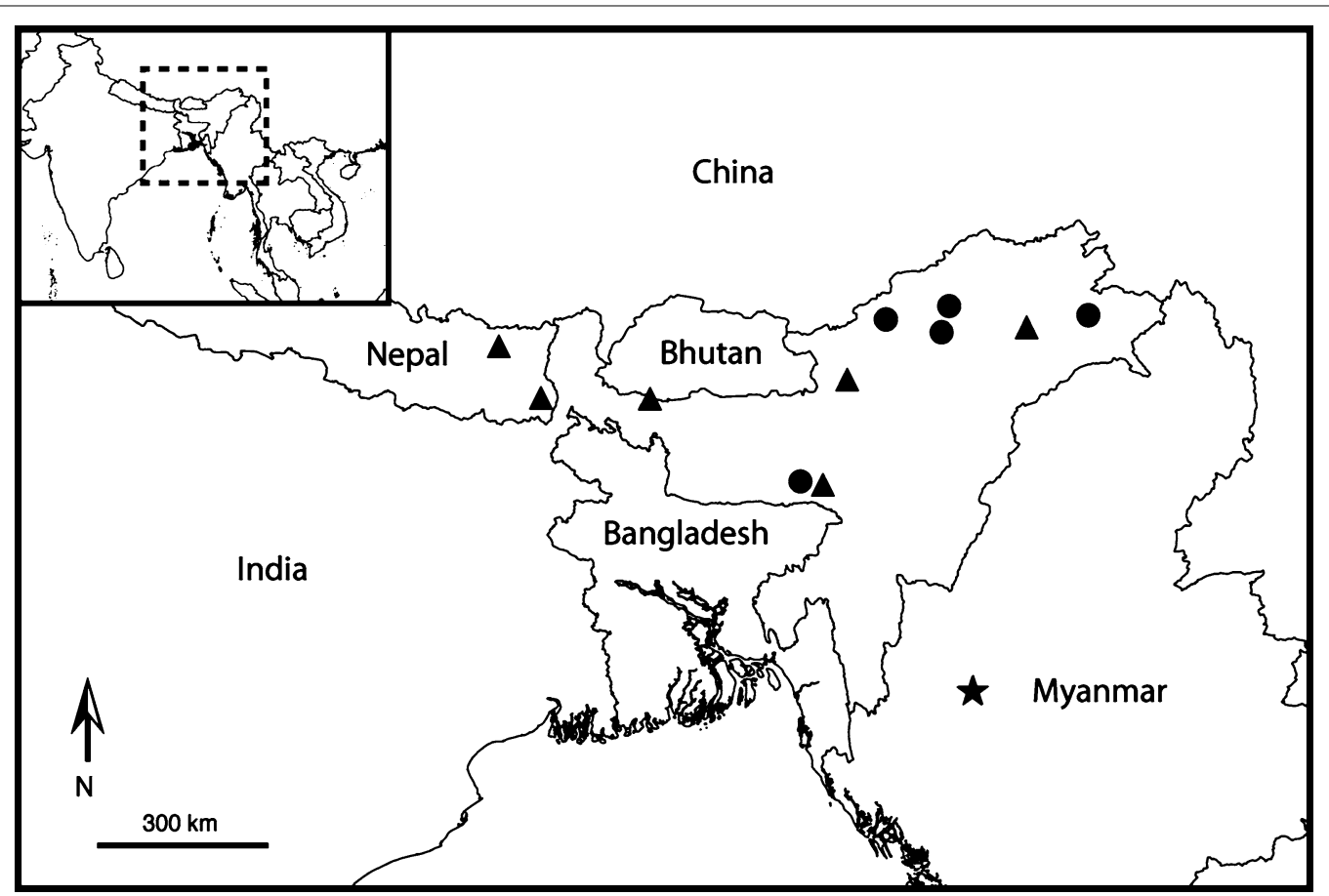

Fig. 5 Distribution map of Begonia griffithiana (circle), B. myanmarica (star), B. nepalensis (trangle). Distribution data of B. griffithiana and B. nepalensis is based on GPS data in the Begonia Resource Center (Hughes et al. 2015)

but not clustered within sect. Monopteron clade (Fig. 6), suggesting that the fruit morphology of a single developed wing in the ovary/fruit is homoplasious. Morphologically, the key characters for sect. Platycentrum-sect. Sphenanthera clade are evergreen, rhizomatous and two locules in ovary (Leong 2017). Begonia myanmarica is evergreen with stout rhizome, but having 1-locular ovary. Compared with other species in sect. Platycentrum-sect. Sphenanthera, B. myanmarica is unique with a single developed wing and having 1-locular ovary not known in any other taxa in this clade. Further studies with increasing sampling of Myanmar Begonia are needed to place $B$. myanmarica in its proper infrageneric position.

\section{Conclusion}

Studies of morphology, molecular phylogenetics and cytology support the recognition of the new species, Begonia myanmarica, which is fully described and illustrated. Our results also indicate that B. myanmarica is not closely related to species previously assigned to sect. 


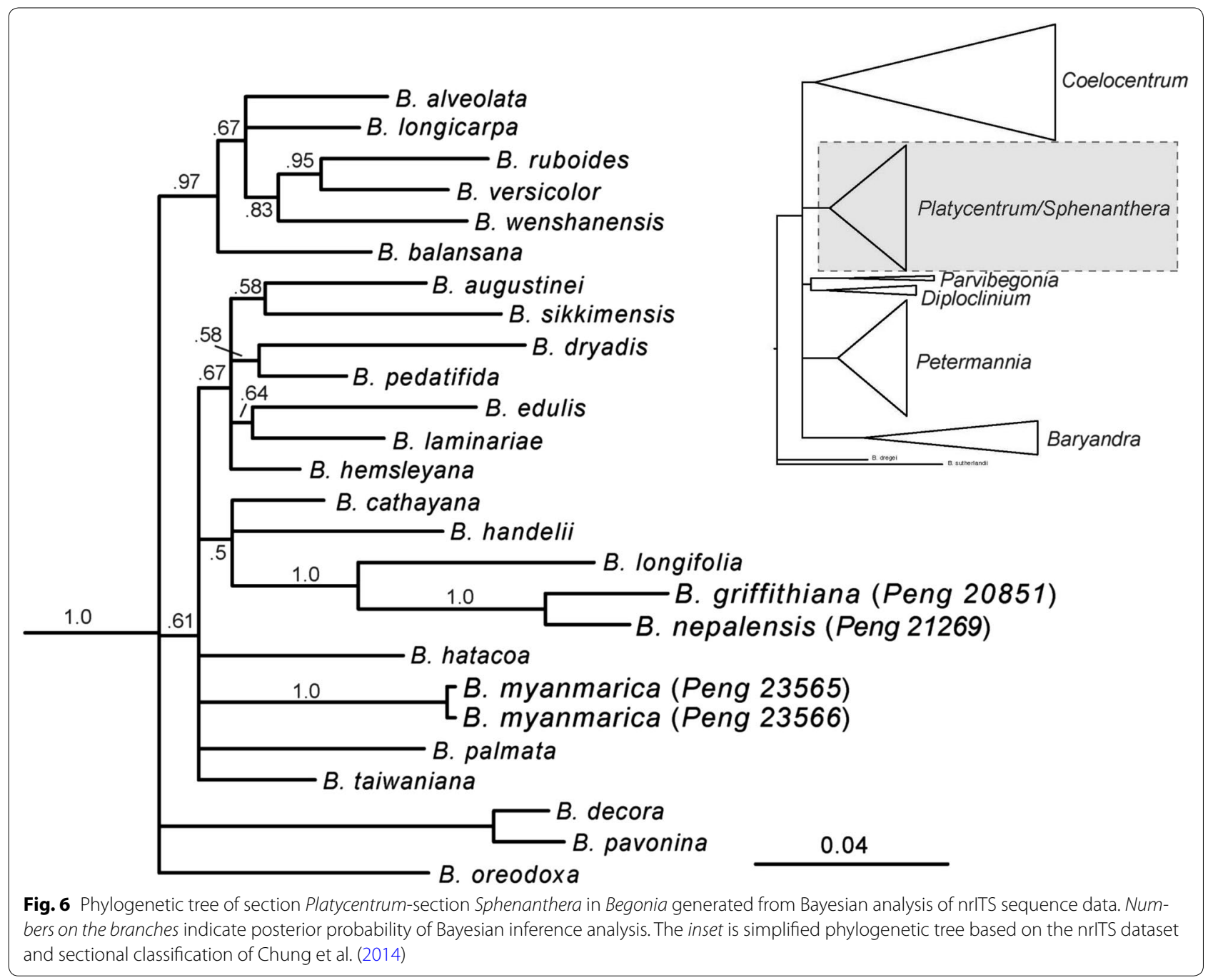

Monopteron, suggesting that the fruit morphology of a single developed wing in the ovary/fruit characterizing sect. Monopteron is homoplasious.

\section{Authors' contributions}

YDK, KMH, and SHC conducted the fieldwork and collected the new species from Myanmar; YDK and CIP took color photographs of B. myanmarica from the wild and the experimental greenhouse respectively; YHT carried out the morphological observation and undertook laboratory analyses; YK carried out the cytological study; YHT, CIP and KFC prepared the manuscript. All authors read and approved the final manuscript.

\section{Author details}

${ }^{1}$ Research Museum and Herbarium (HAST), Biodiversity Research Center, Academia Sinica, Taipei 11542, Taiwan. ${ }^{2}$ Department of Life Science, Hallym University, Chuncheon, Gangwon 24252, Republic of Korea. ${ }^{3}$ Popa Mountain Park, Nature and Wildlife Conservation Division, Ministry of Natural Resources and Environmental Conservation, Kyaukpadaung Township, Mandalay Region, Myanmar. ${ }^{4}$ International Biological Material Research Center, Korea Research Institute of Bioscience and Biotechnology, Daejeon 34141, Republic of Korea.

\section{Acknowledgements}

This work was supported by grants from the National Institute of Biological Resources (NIBR), the Ministry of Environment (MOE) of the Republic of Korea (NIBR2016 04201) and Biodiversity Research Center, Academia Sinica, Taiwan.
Our gratitude extends to the Ministry of Natural Resources and Environmental Conservation of Myanmar for the continuous guidance and support for this project. We are indebted to Dr. Rekha Morris who provided research materials of B. griffithiana and B. nepalensis for cytological study; Mr. Ku-Feng Lin, manager of Academia Sinica greenhouse, for providing facilities and assistance to maintain the Begonia living collections.

Competing interests

The authors declare that they have no competing interests.

\section{Publisher's Note}

Springer Nature remains neutral with regard to jurisdictional claims in published maps and institutional affiliations.

\section{Appendix}

Voucher information and GenBank accession numbers in newly generated sequences and morphological observation are listed here. Voucher data is given using following format: Taxon name, Collection locality, collector(s) and collector number (herbarium for voucher specimen), GenBank accession numbers for nrITS. Other nrITS sequences refer to Chung et al. (2014). 


\section{Newly generated sequences}

Begonia myanmarica C.I Peng \& Y.D. Kim, Myanmar, Peng 23565 (HAST), KY088184; Peng 23566 (HAST), KY088185. Begonia griffithiana Warb., India, Peng 20851 (HAST), KY088186. Begonia nepalensis Warb., India, Peng 20854 (HAST), KY088187.

\section{Other sequences from Chung et al. (2014)}

Begonia aequata A. Gray, AF485147; Begonia alicida C.B.Clarke ex Hook. f., KF636419; Begonia alveolata Yu, AY048977, Begonia amphioxus Sands, AF485150; Begonia arachnoidea C.I Peng, Yan Liu \& S.M. Ku, KF636420; Begonia augustinei Hemsl., KF636421; Begonia auritistipula Y.M. Shui \& W.H. Chen, KF636422; Begonia austroguangxiensis Y.M. Shui \& W.H. Chen, KF636423; Begonia balansana Gagnep., AF485091; Begonia bamaensis Yan Liu \& C.I Peng, KF636424; Begonia bataiensis Kiew, KF636425; Begonia berhamanii Kiew, KF636426; Begonia bipinnatifida J.J.Sm., KF636427; Begonia boisiana Gagnep., AF534719; Begonia bolsteri Merr., KF636428; Begonia brevipes Merr., KF636429; Begonia brevirimosa Irmsch., AF485145; Begonia cathayana Hemsl., AF280106; Begonia cavaleriei H.Lév., KF636430; Begonia chingii Irmsch., KF636432; Begonia cirrosa L.B.Sm. \& Wassh., AY048979; Begonia contracta Warb., KF636433; Begonia cylindrica D.R.Liang \& X.X.Chen, KF636434; Begonia decora Stapf, KF636435; Begonia dipetala Graham, AF469124; Begonia dregei Otto \& A.Dietr., AY429336; Begonia dryadis Irmsch., KF636436; Begonia edulis H.Lév., KF636437; Begonia erythrogyna Sands, KF636438; Begonia fimbristipula Hance, KF636439; Begonia fuscisetosa Sands, KF636440; Begonia goegoensis N.E.Br., AF485138; Begonia grandis subsp. holostyla Irmsch., AF485088; Begonia griffithiana Warb., KY088186; Begonia gueritziana Gibbs, KF636441; Begonia guixiensis Yan Liu, S.M. Ku, C.I Peng, KF636442; Begonia hainanensis Chun \& F.Chun, KF636443; Begonia handelii Irmsch., AY048982; Begonia hatacoa Buch.Ham. ex D. Don, KF636444; Begonia hemsleyana Hook. f., AF485099; Begonia hernandioides Merr., KF636445; Begonia inostegia Stapf, KF636446; Begonia isoptera Dryand. ex Sm., KF636447; Begonia jingxiensis D. Fang \& Y.G. Wei, KF636448; Begonia kinabaluensis Sands, KF636450; Begonia kingiana Irmsch., KF636451; Begonia labordei H.Lév., KF636452; Begonia lagunensis Elmer, KF636453; Begonia lambii Kiew, KF636454; Begonia laminariae Irmsch., KF636455; Begonia lanternaria Irmsch., KF636456; Begonia leprosa Hance, KF636457; Begonia liuyanii C.I Peng, S.M. Ku \& W.C. Leong, KF636458; Begonia longa C.I Peng \& W.C. Leong, KF636459; Begonia longicarpa K.Y. Guan \& D.K. Tian, AY048985; Begonia longifolia Blume, AF485105; Begonia longistyla Y.M.Shui \& W.H.Chen, KF636460; Begonia luzhaiensis T.C. Ku,
KF636461; Begonia madaiensis Kiew, KF636462; Begonia masoniana Irmsch. ex Ziesenh., KF636463; Begonia merrittii Merr., KF636464; Begonia nigritarum Steud., KF636465; Begonia ningmingensis D. Fang, Y.G. Wei \& C.I Peng, KF636466; Begonia oreodoxa Chun \& F.Chun ex C.Y.Wu \& T.C.Ku, KF636467; Begonia oxysperma A.DC., AF485131; Begonia palmata D.Don, KF636468; Begonia panayensis Merr., KF636469; Begonia paracauliflora sp. ined., KF636470; Begonia parvula H. Lév. \& Vaniot, KF636471; Begonia pavonina Ridl., KF636472; Begonia pedatifida H.Lév., KF636473; Begonia peltatifolia H.L. Li, KF636474; Begonia pengii S.M. Ku \& Yan Liu, KF636475; Begonia pseudolateralis Warb., KF636476; Begonia pulvinifera C.I Peng \& Yan Liu, KF636477; Begonia ramosii Merr., KF636478; Begonia ravenii C.I Peng \& Y.K.Chen, KF636479; Begonia retinervia D.Fang, D.H.Qin \& C.I Peng, KF636480; Begonia ruboides C.M. $\mathrm{Hu}$ ex C.Y.Wu \& T.C.Ku, KF636481; Begonia rufipila Merr., KF636482; Begonia semiparietalis Yan Liu, S.M.Ku \& C.I Peng, KF636483; Begonia serratipetala Irmsch., KF636484; Begonia sikkimensis A.DC., KF636485; Begonia sinofloribunda Dorr, KF636486; Begonia subnummularifolia Merr., KF636487; Begonia sutherlandii Hook. f., AF485215; Begonia symsanguinea L.L. Forrest \& Hollingsw., AF485151; Begonia taiwaniana Hayata, KF636488; Begonia variabilis Ridl., AY753732; Begonia variegata Y.M. Shui \& W.H.Chen, KF636489; Begonia versicolor Irmsch., AF485090; Begonia wadei Merr. \& Quisumb., KF636490; Begonia wenshanensis C.M. Hu ex C.Y. Wu \& T.C. Ku, AY048974; Begonia yappii Ridl., KF636491.

\section{Morphological observation}

Begonia myanmarica C.I Peng \& Y.D. Kim, Myanmar, Peng 23565 (HAST); Peng 23566 (HAST). Begonia griffithiana Warb., India, Peng 20851 (HAST). Begonia nepalensis Warb., India, Peng 20854 (HAST).

Begonia cathayana Hemsl., China, Peng 20288 (HAST). Begonia decora Stapf, Malaysia, Peng 20261 (HAST). Begonia dryadis Irmsch., China, Peng 18016 (HAST). Begonia edulis H.Lév., China, Peng 18747 (HAST). Begonia hatacoa Buch.-Ham. ex D. Don, Peng 20861 (HAST). Begonia hemsleyana Hook. f., China, Peng 17590 (HAST). Begonia laminariae Irmsch., China, Peng 17447 (HAST). Begonia oreodoxa Chun \& F. Chun ex C.Y. Wu \& T.C. Ku, China, Peng 20454 (HAST). Begonia palmata D. Don, Taiwan, Peng 20993 (HAST). Begonia pavonina Ridl., Malaysia, Peng 20239 (HAST). Begonia pedatifida H. Lév., China, Peng 18779 (HAST). Begonia sikkimensis A. DC., China, Peng 20848 (HAST). Begonia augustinei Hemsl., China, Peng 20759 (HAST). Begonia versicolor Irmsch., China, Peng 18688 (HAST). Begonia balansana Gagnep., Vietnam, Peng 21928 (HAST). Begonia handelii 
Irmsch., China, Peng 17513 (HAST). Begonia longifolia Blume, Taiwan, Peng 16795 (HAST).

Received: 29 November 2016 Accepted: 30 March 2017

Published online: 07 April 2017

\section{References}

Christenhusz MJM, Byng JW (2016) The number of known plants species in the world and its annual increase. Phytotaxa 261(3):201-217. doi:10.11646/ phytotaxa.261.3.1

Chung K-F, Leong W-C, Rubite RR, Repin R, Kiew R, Liu Y, Peng C-I (2014) Phylogenetic analyses of Begonia sect. Coelocentrum and allied limestone species of China shed light on the evolution of Sino-Vietnamese karst flora. Bot Stud 55:1. doi:10.1186/1999-3110-55-1

de Candolle A (1864) Begoniaceae. In: de Candolle A (ed) Prodromus systematis naturalis regni vegetabilis. Treuffel et Würtz, Masson, pp 266-408

Doorenbos JM, Sosef MS, de Wilde JJFE (1998) The sections of Begonia including descriptions, keys and species lists: studies in Begoniaceae VI. Wageningen Agricultural University, Wageningen

Forrest LL, Hollingsworth PM (2003) A recircumscription of Begonia based on nuclear ribosomal sequences. Plant Syst Evol 241(3):193-211. doi:10.1007/s00606-002-0033-y

Huelsenbeck JP, Ronquist F (2001) MRBAYES: Bayesian inference of phylogenetic trees. Bioinformatics 17(8):754-755. doi:10.1093/ bioinformatics/17.8.754

Hughes M (2008) An annotated checklist of Southeast Asian Begonia. Royal Botanic Garden Edinburgh, Edinburgh

Hughes M, Moonlight PW, Jara A, Pullan M (2015) Begonia Resource Centre. http://padme.rbge.org.uk/begonia. Accessed 15 July 2016

Ku T-C (1999) Begoniaceae. In: Ku T-C (ed) Flora Reipublicae Popularis Sinicae, vol 52, no 1. Science Press, Beijing, pp 126-269

Ku C-Z, Peng C-I, Turland NJ (2007) Begoniaceae. In: Raven PH, Hong D-Y (eds) Flora of China, vol 13., Science Press, Beijing \& Missouri Botanical Garden Press, St. Louis, pp 153-207

Legro RAH, Doorenbos J (1971) Chromosome numbers in Begonia II. Neth J Agric Sci 19:176-183

Leong, W-C (2017) Molecular phylogenetics of Asian Begonia (Begoniaceae): systematics and biogeographic implications. PhD Dissertation, National Taiwan University

Maddison WP, Maddison DR (2015) Mesquite: a modular system for evolutionary analysis, version $3.03 \mathrm{ed}$. http://mesquiteproject.org. Accessed $7 \mathrm{Mar}$ 2015
Peng C-I, Jin X-H, Ku S-M, Kono Y, Huang H-Y, Yang H-A (2014a) Begonia wuzhishanensis (sect. Diploclinium, Begoniaceae), a new species from Hainan Island, China. Bot Stud 55:24, doi:10.1186/1999-3110-55-24

Peng C-I, Wang H, Kono Y, Yang H-A (2014b) Begonia wui-senioris (sect. Platycentrum, Begoniaceae), a new species from Myanmar. Bot Stud 55:13. doi:10.1186/1999-3110-55-13

Posada D, Crandall KA (1998) MODELTEST: testing the model of DNA substitution. Bioinformatics 14(9):817-818. doi:10.1093/Bioinformatics/14.9.817

Rajbhandary S (2010) Systematic revision of the genus Begonia L. (Begoniaceae) in the Himalayas. PhD dissertation, Tribhuvan University

Rajbhandary S, Hughes M, Phutthai T, Thomas DC, Krishna KS (2011) Asian Begonia: out of Africa via the Himalayas? Gard Bull (Singapore) 63(1 \& 2):277-286

Rubite RR (2010) Systematic studies on Philippine Begonia L. secion Diploclinium (Lindl.) A.D.C. (Begoniaceae). PhD dissertation, De La Salle University

Sharma AK, Bhattacharyya UC (1961) Cytological studies in Begonia II. Caryologia 14:279-301

Shui Y-M, Peng C-I, Wu C-Y (2002) Synopsis of the Chinese species of Begonia (Begoniaceae), with a reappraisal of sectional delimitation. Bot Bull Acad $\operatorname{Sin} 43(4): 313-327$

Tamura K, Peterson D, Peterson N, Stecher G, Nei M, Kumar S (2011) MEGA5: molecular evolutionary genetics analysis using maximum likelihood, evolutionary distance, and maximum parsimony methods. Mol Biol Evol 28(10):2731-2739. doi:10.1093/molbev/msr121

Tanaka N, Hayami Y (2011) Begonia kachinensis (sect. Sphenanthera Begoniaceae), a new species from Myanmar. Acta Phytotax Geobot 61(3):151-154

Tanaka N, Hughes M (2007) Begonia (Sect Sphenanthera) hayamiana (Begoniaceae), a new species of Begonia (Begoniaceae) from Northern Myanmar. Acta Phytotax Geobot 58(2-3):83-86

Tanaka N, Peng C-I (2016) Begonia togashii (Begoniaceae: sect. Platycentrum), a new species from central Myanmar. Acta Phytotax Geobot 67(3):191-197. doi:10.18942/apg.201608

Tebbitt MC, Lowe-Forrest L, Santoriello A, Clement WL, Swensen SM (2006) Phylogenetic relationships of Asian Begonia, with an emphasis on the evolution of rain-ballist and animal dispersal mechanisms in sections Platycentrum, Sphenanthera and Leprosae. Syst Bot 31(2):327-336. doi:10.1600/036364406777585784

Thomas DC (2010) Phylogenetics and historical biogeography of Southeast Asian Begonia L. (Begoniaceae). PhD dissertation, University of Glasgow

Thomas DC, Hughes M, Phutthai T, Rajbhandary S, Rubite R, Ardi WH, Richardson JE (2011) A non-coding plastid DNA phylogeny of Asian Begonia (Begoniaceae): evidence for morphological homoplasy and sectional polyphyly. Mol Phylogenet Evol 60(3):428-444. doi:10.1016/j. ympev.2011.05.006

\section{Submit your manuscript to a SpringerOpen ${ }^{\circ}$ journal and benefit from:}

- Convenient online submission

- Rigorous peer review

- Immediate publication on acceptance

- Open access: articles freely available online

- High visibility within the field

- Retaining the copyright to your article

Submit your next manuscript at $\boldsymbol{\nabla}$ springeropen.com 